\title{
The Impact of Teacher Self-efficacy on the Students' Motivation and Achievement
}

\author{
Ahmad Mojavezi \\ Deparment of English, Islamic Azad University, Zahedan Branch, Zahedan, Iran \\ Email: a.mojavezi@gmail.com \\ Marzieh Poodineh Tamiz \\ Deparment of English, Islamic Azad University, Zahedan Branch, Zahedan, Iran \\ Email: m.poodineh@gmail.com
}

\begin{abstract}
The study of self-efficacy and its impact on human performance has intrigued a lot of scholars during the last two decades (e.g. Clayson, D. \& Sheffet, M. 2006; Nauta, M. 2001; Muijs \& Rejnolds, 2001; Bandura, 1997; Podell \& Soodak, 1993). The objective of this research was to investigate the influence of teacher self-efficacy (TSE) on the students' motivation and achievement. To this end, eighty senior high school teachers in four different cities in Iran, and one hundred and fifty senior high school students, based on their teachers' level of self-efficacy, have been selected randomly. For data collection, two instruments were employed: Teacher Self-Efficacy and Students' Motivation questionnaires. Data were analyzed through Pearson product-moment correlation coefficient and ANOVA. The results of the study revealed that teacher self-efficacy has a positive influence on the students' motivation and achievement. The results of the study and their pedagogical implications are discussed, and recommendations for further research are provided.
\end{abstract}

Index Terms — self-efficacy, teacher self-efficacy, students' motivation, students' achievement

\section{INTRODUCTION}

The role of self-efficacy in teaching and learning continues to intrigue researchers and practitioners. Previous research has provided empirical evidence in supporting the effectiveness of teacher self-efficacy, or the extent to which a teacher believes that he or she can influence the students' outcome, in educational contexts (Podell \& Soodak, 1993; Muijs \&Rejnolds, 2001; Tschannen-Moran \& Hoy 2001). Studies have indicated that teacher self-efficacy has been associated with teacher effort and persistence in encountering difficulties (Gibson \& Dembo, 1984; Podell \&Soodak, 1993), self-efficacy beliefs and academic performance and persistence (Martin \& Marsh, 2006; Skaalvik \& Skaalvik, 2004), professional commitment (Evans \& Tribble, 1986), openness to new methods in teaching and positive teacher behavior (Guskey, 1988) and using more humanistic, positive, or teacher-based strategies to deal with student problems (Woolfolk, Rosoff, \& Hoy, 1990).

Although a substantial body of research (e.g., Gibson \& Dembo, 1984; Ashton and Webb 1986 ;Rushton, Morgan, \& Richard 2007) has revealed that TSE has influence on teachers and students, unfortunately, such studies have failed to investigate more explicitly the link between teacher self-efficacy and students' motivation and achievement. In addition, few studies have explored the validity of TSE across groups of teachers in different settings.

The purpose of this study was two-fold: The first purpose was to examine whether there is any significant relationship between teacher self-efficacy and students' motivation, and the second purpose was to examine if there is any difference in students' achievement based on their teachers' level of self- efficacy.

\section{REVIEW OF LITERATURE}

Studies on teacher self-efficacy have largely been conceptualized within Bandura's (1994, 2002) notion of selfefficacy. Teacher self-efficacy has been defined as the extent to which a teacher is confident enough to his or her ability to promote students' learning (Bandura, 1994). According to Bandura, human behavior is motivated by the interaction of two kinds of expectations: Self efficacy and outcome expectancy; the former referring to peoples' judgments of their capability to undertake and execute successfully a specific task in a specific context, and the latter including judgments about the likely consequences that this performance would bring about.

Ashton and Webb (1986) recognized that highly efficacious teachers tend to be more organized, display greater skills of instruction, questioning, explaining, and providing feedback to students having difficulties, and maintaining students on task. Low efficacy teachers, on the other hand, display a more custodial than humanistic approach to classroom management, spend significantly more time in group work as opposed to whole group instruction, feel angered and threatened by misbehavior, and experience difficulty in maintaining students on task. 
Finally, according to Smylie (1989), teachers with high self-efficacy are much more likely to provide opportunities for student communication by using a variety of models to meet the needs of all learners (working individually, in pairs, and in groups). Research has also substantiated that teachers with high level of self-efficacy are more likely to divide the class into small groups rather than teaching the class as a whole, thereby allowing the opportunity for more individualized instruction (Tschannen-Moran, 2001)

\section{A. Teacher Self-efficacy and Students' Motivation}

According to Pintrich \& Schunk (2003) motivation is "a process for goal-directed activity that is instigated and sustained" (p.5). According to Gardner motivation theory (1985) students are motivated to learn and achieve when they perceive their teachers care about them. Teachers who care were described as demonstrating democratic interaction styles, developing expectations for student behavior in light of individual differences, modeling a "caring" attitude toward their own work, and providing constructive feedback.

Moreover, efficient teachers encourage students for understanding. They treat students' misunderstandings in the subject and they utilize different visual aids in order to make the subject more enticing and meaningful. Additionally, they give students opportunities to engage in conversations and give substantive feedback rather than scores on assignments. Additionally, there is some evidence that teachers' affect, like enthusiasm for learning and their sensitivity concerning students' treatment, might affect students' emotions related to the objectives (Stipek et. al., 1998).

The relationships between teachers and students also influences classroom climate; Teachers are responsible for regulating the classroom environment, including regulating classroom discipline, implementation of approaches and methods to learning, interacting with the students in the classroom. Wentzel (1994) found that students' perceptions of positive affinity with their teachers were related to their pursuit of pro-social classroom goals such as getting along with others and being socially responsible, and were more strongly correlated to student interest in school than perceived support from parents and peers.

Perceived support from teachers also is a positive predictor of effort in schools and the pursuit of social responsibility goals, including acting in pro-social ways that encourage peer cooperation (Wentzel, 1994). Conversely, students who perceive teachers as harsh and cold are found to consistently display poor social behavior and low social goals as well as to achieve lower academically, in comparison with their peers (Wentzel 1998).

Students care about their relationships with their teachers and respond with greater engagement and effort when they believe that their teachers care about them and are supportive. One way that teachers convey these qualities is through their discourse with their students in the classroom. Classroom discourse structure concerns the manner in which teachers engage student participation in learning, promote intrinsic motivation, and balance appropriate challenges with skill levels.

\section{B. Teacher Self-efficacy and Students' Achievement}

A number of studies have elaborated about the influence of teacher self-efficacy beliefs on children's achievement and success at school (Muijs \&Rejnolds, 2001; Tournaki\& Podell, 2005). Teacher's self- efficacy beliefs may influence a student's achievement in several ways: teachers with high self-efficacy beliefs are more likely than teachers with a low sense of self-efficacy to implement didactic innovations in the classroom, to use classroom management approaches and adequate teaching methods and encourage students' autonomy, and to take responsibility for students with special learning needs (Allinder, 1994), to manage classroom problems (Chacon, 2005), and to keep students on task (Podell\& Soodak, 1993).

Ross (1992) investigated the relationship between student achievement, teacher efficacy, an interaction with assigned coaches on a sample of 18 grade 7 and 8 history teachers in 36 classes. The result of the study indicated that students' achievement was higher in classrooms of teachers who had more contact with their coaches, and in classrooms of teachers with greater confidence in the effectiveness of education.

In addition, Tournaki and Podell (2005) gathered data from three hundred and eighty-four general education teachers in order to examine how the interaction between student and teacher characteristics affects teachers' predictions of students' academic and social success. The participants responded to one of 32 possible case studies describing a student, in which gender, reading achievement, social behavior, and attentiveness were manipulated experimentally, and to a 16-item teacher-efficacy scale. Their findings indicated that teachers with high efficacy made less negative predictions about students, and seemed to adjust their predictions when student characteristics changed, while low efficacy teachers seemed to be paying attention to a single characteristic when making their predictions. Also, all teachers responded similarly to students who exhibited a combination of aggressive and inattentive behaviors, that is, if students were friendly, inattentiveness were tolerated more than if they were aggressive. Furthermore, all teachers made higher predictions of academic success for students reading on grade level even when they were aggressive, than for students reading below grade level even when they were friendly.

The necessarily brief review of studies has indicated the paucity of practical work on investigating the impact of teacher self-efficacy on the students' motivation and achievement in the ESL classroom. This provides a good justification for more studies in the areas. To this aim, this research addressed the following research questions:

1. Is there any relationship between teacher self-efficacy and students' motivation?

2. what is the impact of teacher self-efficacy on the students' achievement? 


\section{METHOD}

\section{A. Participants}

The participant of this study comprised of two groups: the first group consisted of eighty senior high school teachers in four different cities of Iran. The teachers were both male $(\mathrm{N}=40,50 \%)$ and female $(\mathrm{N}=40,50 \%)$. Most teachers reported having a BA degree in English $(\mathrm{N}=68,85 \%)$. The mean age of the participants was $31.68(\mathrm{SD}=5.71)$ and their average years of experience was 10.17. The second group of participants consisted of 150 students in different cities. The students actually belonged to the classes whose teachers contributed to this study. That is, after completing the questionnaire, the teachers were divided into three groups, based on their level of self-efficacy. Of each group, five teachers were selected randomly. The researcher then asked 10 students, of each selected teacher, to fill out the students' motivation questionnaire. Of all 150 students who participated in the study 30 students were excluded in further investigation because they did not complete the questionnaire thoroughly. Multiple responses to individual items were also treated as unanswered, and were deleted from further scrutiny.

\section{B. Instruments}

For the purpose of data collection, two instruments were employed in this study:

1. The teacher self-efficacy Questionnaire, developed by Tschannen-Moran \& Hoy (2001). This questionnaire included 24 items which examined the teacher's idea about his/her effective control over Instructional Strategies $(8$ items), Classroom management (8 items), and Student Engagement (8 items). It used a 5-point Likert scale (ranging from 1(Nothing) to 5(A great deal)), to rank the teachers' level of self-efficacy. The items were translated into Persian, and checked for their meaningfulness by the researchers. The questionnaire was then piloted to ensure the researchers of the appropriate timing, and administration procedures, and also to avoid ambiguity and other related problems in the main study.

Using Cronbach alpha, the reliability estimates of the questionnaire was calculated. The reliability coefficient of the questionnaire was .76, showing a reasonably acceptable index of reliability coefficient.

2. Students' Motivation questionnaire (Appendix A) consisted of four parts: The first and the second parts elicit information on students' intrinsic (items 1-7) and extrinsic motivation (items 8-12), adopted from Schmidt (1996), the third part seeks out information on students' attitude toward learning English (items 13-18), adopted from Gardner (1986), and the fourth part shows students' opinion about the teacher (items 19-25), developed by the researcher. In order to examine the validity of the fourth part of the questionnaire (i.e., the students' opinions about the teacher), it was first reviewed by 8 experts in different universities; According to the experts' opinion, some of the items were deleted, and some others were modified.

Factor analysis was conducted on the students' motivation questionnaire to identify how the items in the questionnaire functioned, and whether they load on different factors. They could be actually classified into four groups.

To run factor analysis, the preliminary tests of the factorability of data were conducted. The result indicated that factor analysis was appropriate and could result in reliable information. Table 3.1 shows the results of tests of factorability of data.

TABLE 3.1.

TESTS OF FACTORABILITY OF DATA

\begin{tabular}{|lc|l|}
\hline Kaiser-Meyer-Olkin Measure... & \multicolumn{1}{|c|}{.815} \\
Bartlett's Test of Sphericity $\quad$ Approx. Chi-Square & 2830.755 \\
& Df & 300 \\
& Sig.Bartlett & .000 \\
\hline
\end{tabular}

According to the above table, Kaiser- Meyer-Olkin value was .815 , exceeding the recommended value of .6, and Barlette's Test of Sphericity showed significant, supporting the factorability of the data.

The Screeplot (table 3.2), however, revealed that there was a clear break after the fourth component. In other words, after the fourth component the shape of the cure changed its direction and became, nearly, horizontal, which meant just four components were suitable for analysis. 
TABLE 3.2

SCREEPLOT ON THE STUDENTS' MOTIVATION ITEMS

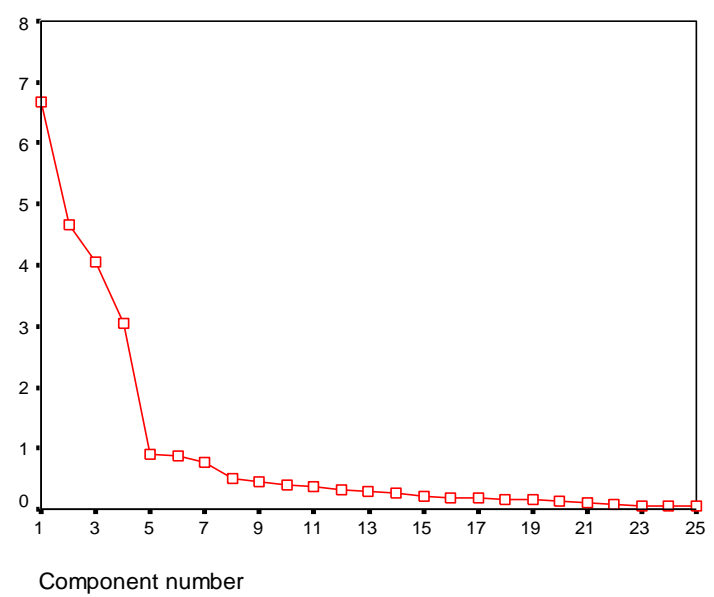

The reason for running factor analysis on the data was to ensure statistically the items were related to each aspect of the students' motivation. Table 3.3 shows the student motivation items loaded on four different factors.

TABLE 3.3.

VARIMAX ROTATION OF FOUR FACTOR SOLUTION

\begin{tabular}{|c|c|c|c|c|}
\hline Items & $\begin{array}{l}\text { Comonent1: Extrinsic } \\
\text { motivation }\end{array}$ & $\begin{array}{l}\text { Component 2: Opinion } \\
\text { about the teacher }\end{array}$ & $\begin{array}{l}\text { Component 3: Attitude } \\
\text { toward learning English }\end{array}$ & $\begin{array}{l}\text { Component 4: } \\
\text { intrinsic motivation }\end{array}$ \\
\hline $\begin{array}{l}\text { Item } 2 \\
\text { Item } 3 \\
\text { Item } 4 \\
\text { Item } 5 \\
\text { Item } 6 \\
\text { Item } 1 \\
\text { Item } 7 \\
\text { Item } 19 \\
\text { Item } 20 \\
\text { Item } 21 \\
\text { Item } 22 \\
\text { Item } 23 \\
\text { Item } 24 \\
\text { Item } 25 \\
\text { Item } 13 \\
\text { Item } 14 \\
\text { Item } 15 \\
\text { Item } 16 \\
\text { Item } 17 \\
\text { Item } 18 \\
\text { Item } 9 \\
\text { Item } 10 \\
\text { Item } 8 \\
\text { Item } 11 \\
\text { Item } 12 \\
\% \text { of variance } \\
\text { Explained }\end{array}$ & $\begin{array}{l}.966 \\
.897 \\
.881 \\
.878 \\
.869 \\
.859 \\
.854 \\
\\
\\
\\
\\
\end{array}$ & $\begin{array}{l}.882 \\
.879 \\
.857 \\
.839 \\
.816 \\
.695 \\
.542 \\
\end{array}$ & $\begin{array}{l}.934 \\
.849 \\
.817 \\
.817 \\
.758 \\
.739 \\
\end{array}$ & $\begin{array}{l} \\
\\
\\
\\
\\
\\
\\
\\
\\
\\
\\
\\
.932 \\
.911 \\
.885 \\
.879 \\
.841 \\
12.196 \%\end{array}$ \\
\hline
\end{tabular}

As indicated in the above table, factor analysis, and its later Varimax rotation revealed the presence of four components on which the items in the questionnaire were loaded strongly. This supported the idea that the questionnaire had four groups of items which addressed intrinsic motivation, extrinsic motivation, attitude toward English, and opinion about the teacher separately. In other words, the result indicated that items related to students' extrinsic motivation loaded strongly on factor 1, items regarding students' opinion about the teacher loaded strongly on factor 2 , items related to students' attitude toward learning English loaded on factor 3, and items related to students' intrinsic motivation loaded strongly on factor 4. More specifically each cluster items loaded separately on a different factor, reporting the multi-construct nature of the questionnaire.

Furthermore, the students' motivation questionnaire was piloted to help the researcher for the appropriate timing, administration procedures, and other related points in the main phase of the study. The pilot study was conducted on 50 students at two different schools in Iran. After piloting the questionnaire, some changes in some of the items were made. In addition, it was decided that the questionnaire be explained verbally in the main study, to avoid any 
misunderstanding by the students. Using Cronbach alpha, the reliability of the whole instrument in the pilot study was estimated. It showed the reliability as .85 , which was quite acceptable for the present study.

\section{Procedures}

The data collection was carried out in June 2011. For each data collection session, after a semi-detailed explanation to the teachers on how they were expected to fill out the questionnaire, they were asked to write their name and school name, but they were assured that all the data received from them will be publicized anonymously. The reason for writing their personal information on the questionnaire was for having their students' scores from their schools, and also selecting some of their students randomly. After that, the self-efficacy questionnaire was distributed among the teacher participants, and they were asked to complete it.

After the teacher participants completed the questionnaire, the data were sorted, and then the teachers were divided into three groups, based on their level of self-efficacy. Of each group, five teachers were selected randomly to select some of their students randomly to fill out the students' motivation questionnaire, and also to collect students' scores form the school that they have been teaching.

The second group of participants comprised 150 students who were selected from four different cities, based on their teachers' level of self-efficacy. After a brief explanation on how to fill out the questionnaire, the questionnaire distributed among them. When the student participants were completed the students' motivation questionnaire, the data were analyzed using SPSS software.

\section{RESULTS}

This study addressed two research questions: in the first research question, the researcher wanted to investigate the relationship between teacher self-efficacy and students' motivation. To this aim, Pearson product-moment correlation was conducted on teacher self- efficacy and students' motivation responses. It was also conducted on teacher selfefficacy and each component of the students' motivation responses. Table 3.1, shows the result of Pearson productmoment correlation coefficient on students' motivation:

TABLE 3.1 .

THE RELATIONSHIP BETWEEN TEACHER SELF- EFFICACY AND STUDENTS’ MOTIVATION

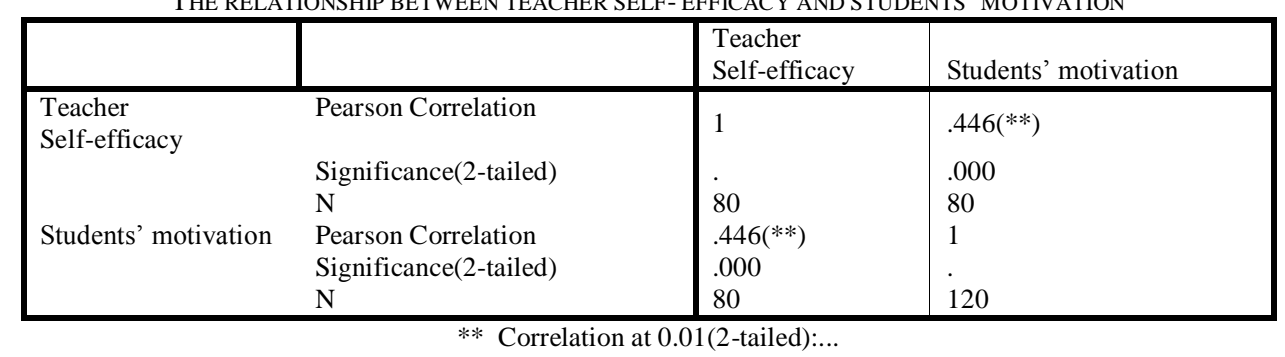

As the above table indicates, a significant correlation coefficient between teacher self-efficacy and students' motivation could be traced. Therefore, it can be inferred that the higher the teacher self-efficacy, the higher the students' motivation. Table 3.2 shows the relationship between teacher self-efficacy and different aspects of students' motivation (i.e., extrinsic motivation, intrinsic motivation, attitude toward learning English, and opinion about the teacher) in this study:

TABLE 3.2.

THE RELATIONSHIP BETWEEN TEACHER SELF-EFFICACY AND DIFFERENT ASPECTS OF THE STUDENTS' MOTIVATION QUESTIONNAIRE

\begin{tabular}{|c|c|c|c|c|c|c|}
\hline & & $\begin{array}{l}\text { Teacher } \\
\text { Self-efficacy }\end{array}$ & Intrinsic & Extrinsic & AAtitude & Opinion \\
\hline \multirow[t]{3}{*}{$\begin{array}{l}\text { Teacher } \\
\text { Self-efficacy }\end{array}$} & Pearson Correlation & 1 & & -.089 & $.793(* *)$ & $.240(*)$ \\
\hline & Significance(2-tailed) & & .000 & .431 & .000 & 0.032 \\
\hline & $\mathrm{N}$ & 80 & 120 & 1120 & 1120 & 1120 \\
\hline
\end{tabular}

As the above table illustrates, there is a reasonably positive correlation between teacher self-efficacy and different aspects of students' motivation: However, for the correlation between teacher self-efficacy and students' extrinsic motivation the result seems interesting: the more the efficacy of the teacher, the less the extrinsic motivation of the students' will be.

The second objective of this research was to investigate if there any difference in students' achievement based on their teacher's level of self-efficacy. To address the above-mentioned objective, one-way ANOVA was conducted. It was to show if there is any significant differences in students' achievement in different groups, based on their teachers' 
level of self-efficacy. The one-way ANOVA was followed by Tukey post-hoc tests to find out where the significant difference among the groups was located. The result of this phase of study in summarized in tables 3.3, and 3.4.

TABLE 3.3.

ONE-WAY ANOVA ON STUDENTS' ACHIEVEMENT BETWEEN THE GROUPS

\begin{tabular}{|l|l|l|l|l|l|}
\hline & Sum of Squares & df & Mean Square & F & Significance \\
\hline Between Groups & 27.757 & 2 & 13.879 & 8.402 & .001 \\
Within Groups & 127.187 & 77 & 1.652 & & \\
Total & 154.944 & 99 & & & \\
\hline
\end{tabular}

As the above Table demonstrates, F value was significant. This shows that there is a significant difference between/ among the groups. It is also necessary to find out where the difference is posited. Thus Tukey Post-hoc tests were conducted (table 3.4) to compare the groups, and to show where the difference is.

TABLE 3.4.

POST-HOC TEST RESULTS ON DIFFERENT GROUPS OF STUDENTS

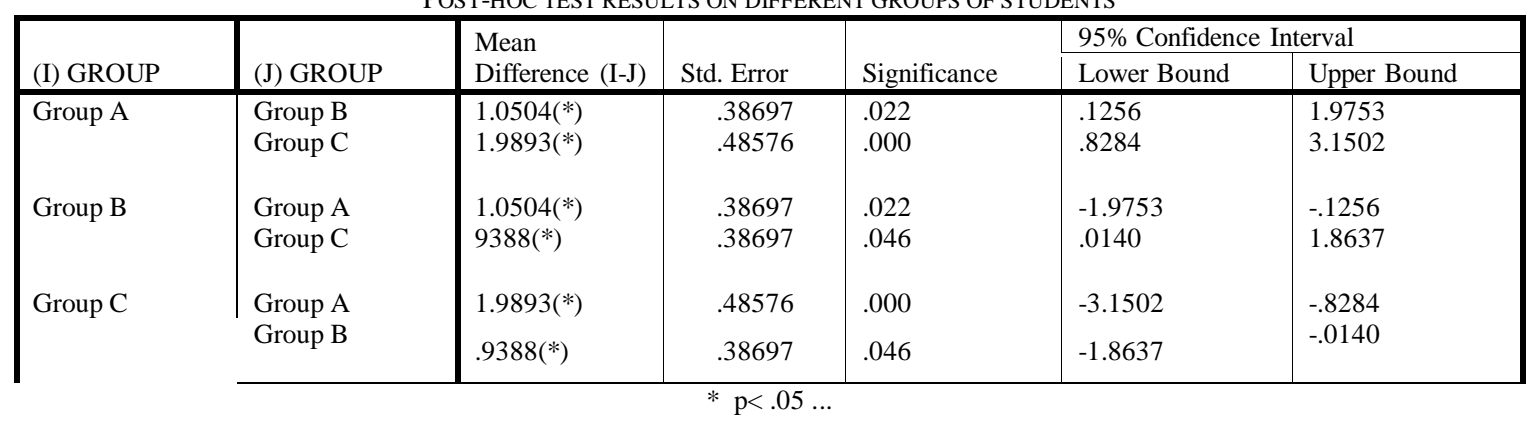

As the above table indicates, Group A performed significantly differently from both groups B (.22) and C (.000). Also students in group B performed better than those in C (.046). Thus it can be inferred that the scores of student group $\mathrm{B}$ is higher than that of group $\mathrm{C}$.

\section{DiscusSION, CONCLUSION, AND IMPLICATION}

This study investigated the relationship between teacher self-efficacy and students' motivation. It was also delved into the impact of teacher self- efficacy on the students' achievement. Pearson product-moment correlation coefficient was conducted between teacher self-efficacy, and students' motivation, and four different aspects of students' motivation (i.e., Extrinsic and Intrinsic motivation, Students' attitude toward learning English, and students' opinion about the teacher), in order to examine whether there is any significant relationship between teacher self-efficacy and students' motivation, and also the different aspects of the students' motivation questionnaire or not. The analyses revealed that there is a reasonably positive correlation between teacher self-efficacy and students' motivation (.446). Thus, it can be argued that teacher self-efficacy positively influence students' motivation. Pearson product-moment correlation also showed a positive correlation between teacher self-efficacy and some aspects of the students' motivation, that is, intrinsic motivation, students' attitude toward learning English, and student opinion about their English teacher. The degrees of correlation were .394, .793, and .240 for intrinsic motivation, students' attitude toward learning English, and students' opinion toward the teacher, respectively. But the results showed little correlation (negatively) between teacher self-efficacy and students' extrinsic motivation.

In educational context like Iran, in which getting good scores in English is a best reward for the student in order to get a good job, to pass the course, and to succeed in the University Entrance Examination is very important. According to the finding in this research, teachers with a higher level of self- efficacy try to change the students' attitude toward learning English and consider English as a favorite subject to students.

This study also investigated the impact of teacher self-efficacy on the students' achievement. To address this phenomenon, ANOVA and post-hoc tests were conducted to examine if there is any difference in students' achievement, based on their teachers' level of self-efficacy. The result of one-way ANOVA revealed that the difference in the students' achievement in different group is significant (.001). Also the F value was significant (8.402). This shows there is a significant difference between the groups based on their achievement. The result of the post- hoc tests also revealed that the students' in group A, who had teachers with higher level of self-efficacy, got better scores than those of group B and C. In other words, it can be inferred that the higher the level of teacher self- efficacy, the higher the students' achievement.

The results of this study support the findings of the previous researches suggesting a significant correlation between teacher self- efficacy and increased students' achievement, by influencing teachers' instructional practices, enthusiasm, commitment, and teaching behavior (Tschannen-Moran \& Hoy, 2001;Tournaki \& Podell .2005; Wolters \& Daugherty, 2007). The results are also in line with Bandura's observation (1994) that teachers who have a strong sense of efficacy 
about their capabilities can motivate their students and improve their cognitive development. However, those who have a low sense of efficacy favor a "custodial orientation that relies heavily on negative sanctions to get students to study". (p. 11).

The results of this study, also, support Gibson \& Dembo (1984) ideas, who maintained that teachers with a high sense of efficacy believe that unmotivated students can be taught, given the extra effort and appropriate techniques. In contrast, teachers with a low sense of instruction efficacy think that they can do little if students are poorly motivated, and the influence which teachers can exert on their students' intellectual development is severely limited by nonsupportive or opposing influences from the home and the community in which the students live, and Moran \&Hoy (2001) ideas that teacher self- efficacy is powerfully related to many meaningful educational outcomes such as teacher persistence, enthusiasm, commitment and instructional behavior, as well as student outcomes such as achievement and motivation.

The current study adds to our understanding of the motivation beliefs of teachers, and provides support for the use of the TSE scale outside of culturally western settings. Thus, we can hypothesize that teacher self-efficacy can influence students' motivation and achievement in different settings and thus it is not context-bound. It is also important that educational contexts, as well as schools' administrators provide clear opportunity in order to enhance teacher selfefficacy and, consequently, improve students' motivation and achievement. For young teachers who have not had adequate opportunity to build successful experience, and for whom self-efficacy may be most malleable, positive modeling and verbal encouragement may be especially important in building self-efficacy (Tschannen-Moran et al. 2007).

Additionally, it seems that personality testing is lagging behind in education compared to the other disciplines. For example, in teacher recruitment, personality testing is either totally neglected, or there is just a subjective evaluation of applicants' personality. By replicating this study with larger samples and in different contexts, applied linguistics researchers can identify the personality characteristics which better fit English language teaching profession. Then, an objective personality testing can be applied to the applicants for this profession as one criterion for their selection, as it is common among other occupational groups. All of these implications seem to be applicable if the society and policy makers change their views towards teaching and education.

The results of this study indicated that there is a positive correlation between teacher self- efficacy and students' motivation and achievement. However, much other valuable information remains to be learned about the role of teacher self- efficacy in teaching. The following ideas for further research evolved out of this study:

1. Further studies can investigate the effect of teacher self- efficacy on students' self- efficacy

2. Further research is needed to investigate the effects of teacher self- efficacy on job satisfaction and teacher burnout.

3. There seems to be a need for further research to determine if teacher efficacy beliefs can be changed by specific administrators' action.

4. There seems a need for further research to investigate whether teacher self- efficacy can affect the amount of parental involvement in teaching.

5. Further research is needed to investigate if the level of teacher self- efficacy differs among beginner and experienced teachers.

\section{APPEndiX A Students’'Motivation Questionnaire}

Dear student

This questionnaire is designed to help us improve teaching English at high schools, and it isn't related to your lesson scores. Please indicate your opinions about each of the following statements by circling the appropriate number. Your answers will be kept strictly confidential.

A1. Answer according to the following scale:

Strongly disagree (1) Moderately disagree (2) slightly agree (3) moderately agree (4) strongly agree (5)

1. The main reason I am taking English class is that my parents want me to improve my English.

(1) (2) (3) (4) (5)

2. I want to do well in English class because it is important to show my ability to my friends.

(1) (2) (3) (4) (5)

3. I want to learn English because it is useful when traveling to many countries.

(1) (2) (3) (4) (5)

4. I am learning English to pass examinations.

(1) (2) (3) (4) (5)

5. I am learning English because English it is my compulsory subject.

(1) (2) (3) (4) (5)

6. If I learn English better, I will be able to get a better job.

(1) (2) (3) (4) (5)

7. I want to learn English because I want to study abroad in the future.

(1) (2) (3) (4) (5) 
8. English is important to me because it will broaden my view.

(1) (2) (3) (4) (5)

9. I want to learn English to learn about people of England and USA.

(1) (2) (3) (4) (5)

10. I want to learn English to get familiarized with the western cultures.

(1) (2) (3) (4) (5)

11. I really enjoy Studying English.

(1) (2) (3) (4) (5)

12. I love learning English.

(1) (2) (3) (4) (5)

13. English is a very important part of the school programme.

(1) (2) (3) (4) (5)

14. I plan to learn English as much as possible.

(1) (2) (3) (4) (5)

15. I would Learn English if it were not our compulsory subject.

(1) (2) (3) (4) (5)

16. Learning English is an enjoyable experience.

(1) (2) (3) (4) (5)

17. I look forward to going to class because learning English is so good.

(1) (2) (3) (4) (5)

18. I really enjoy learning English.

(1) (2) (3) (4) (5)

A2. Answer the following questions according to the following scale:

Nothing (1) Very little (2) some influence (3) Quit a bit (4) A Great deal (5)

19. How much is your English teacher interested in teaching English?

(1) (2) (3) (4) (5)

20. How much is your English teacher interested in English?

(1) (2) (3) (4) (5)

21. How much does your English teacher use different teaching method

(1) (2) (3) (4) (5)

22. How much does your English teacher use Scores to discipline the classroom?

(1) (2) (3) (4) (5)

23. How much does your English teacher motivate you in cooperating?

(1) (2) (3) (4) (5)

24. How much does your English teacher provide feedback to students when they have difficulty in understanding the lessons?

(1) (2) (3) (4) (5)

25. How much is your English teacher tolerance to the students' misbehavior?

(1) (2) (3) (4) (5)

\section{REFERENCES}

[1] Allinder, R. (1994). The relationship between efficacy and the instructional practices of special education teacher and consultants. Teacher Education and Special Education, 17, 86-95

[2] Ashton, P.T., \& Webb, R.B. (1986). Making a difference: Teachers' sense of efficacy and student achievement. New York: Longman

[3] Bandura, A. (1994). Self-efficacy. Encyclopedia of human behavior. Vol. 4, 71-81.

[4] Bandura, A. (2002). social cognitive theory in cultural context. Journal of Applied Psychology: An international Review, 51, 269-290

[5] Chacon, C. (2005). Teachers' perceived efficacy among English as a foreign language teachers in Venezuela. Teaching and Teacher Education. 21, 257-272.

[6] Clayson, D. \& Sheffet, M. (2006). Personality and the student evaluation of teaching. Journal of Marketing Evaluation, 28, 149-160.

[7] Evans, D. E, \& Tribble, M. (1986). Perceived teaching problems, self efficacy, and commitment to teaching among preservice teachers. Journal of Educational research, 80 (2), 81-96.

[8] Friedman, I. A \& Kass, E. (2002). Teacher self-efficacy: a classroom-organization conceptualization. Teaching and Teacher Education, 18, 675-686.

[9] Guo, Y., Laura M. Justice,. Kaderavek J. (2010). Relations among preschool teachers' self-efficacy, classroom quality, and children's language and literacy gains. Teaching and Teacher Education, Volume 26, Issue 4, Pages 1094-1103

[10] Gardner, R.C. (1985). Social Psychology and Second Language Learning. The role of attitude and motivation in Second Language Learning. London: Edward Arnold.

[11] Gibson, S., \& Demo, M. H. (1984). Teacher efficacy: A construct validation. Journal of Educational Psychology, 76 (4), $256-$ 582. 
[12] Guskey, T. R. (1988). Teacher efficacy, self concept, and attitudes toward the implementation of instructional innovation. Teaching and Teacher Education, 4, 63-69.

[13] Martin, A. J., \& Marsh, H. W. (2006). Academic resilience and its psychological and educational correlates: A construct validity approach. Psychology in the Schools, 43, 267-281.

[14] Muijs, R. D., \& Rejnolds, D. (2001). Teachers' beliefs and behaviors: What really matters. Journal of Classroom Interaction, 37, 3-15

[15] Moran, M. \& Hoy, A. (2001). Teacher efficacy: capturing an elusive construct. Teaching and Teacher Education, 17, 783-805.

[16] Nauta, M. (2004). Self efficacy as a mediator of the relationships between personality factors and career interest. Journal of Career Assessment, 12, 381-394.

[17] Tournaki, N., \& Podell, D. (2005). The impact of student characteristics and teacher efficacy on teachers' predictions of student success. Teaching and Teacher Education 21, 299-314

[18] Pintrich, P. R., \& Schunk, D. H. (2002). Motivation in education: Theory, research, and Applications (2 $2^{\text {nd }} E d$.). Columbus, $\mathrm{OH}$ : Merrill-Prentice Hall

[19] Pintrich, P. (2003). A motivational science perspective on the role of student motivation in learning and teaching contexts. Journal of educational Psychology, 95 (4), 667-686.

[20] Podell, D. \& Soodak, L. (1993). Teacher efficacy and bias in special education referrals. Journal of Educational Research, 86, 247-253.

[21] Ross, J. A. (1992) Teacher efficacy and the effect of coaching on student motivation. Canadian Journal of Education, 17, 185190.

[22] Rushton, S., Morgan, J., Richard, M. (2007). Teacher's Myers-Briggs personality profile: Identifying effective teacher personality traits. Teaching and Teacher Education, 23, 432-441.

[23] Skaalvik, E. M., \& Skaalvik, S. (2004). Self-concept and self-efficacy: A test of the internal/external frame of reference model and predictions of subsequent motivation and achievement. Psychological Reports, 95, 1187-1202.

[24] Smylie, M. A. (1989). Teachers' views of the effectiveness of sources of learning to teach. Elementary School Journal, 89, 543-558.

[25] Stipek, D., Givvin, K., Salmon, J., \& MacGyvers, V. (1998). Can a teacher intervention improve classroom practices and student motivation in mathematics? Journal of Experimental Education, 66, 319- 337.

[26] Tschannen-Moran, M. \& Woolfolk Hoy, A. \& Hoy, W. K. (1998) Teacher efficacy: Its meaning and measure, Review of Educational Research, 68, 202-248.

[27] Tschannen-Moran, M., \& Hoy, A. W. (2001). teacher efficacy: Capturing an elusive construct. Teaching and Teacher Education, 17(7), 783-805.

[28] Wentzel, K. R. (1994). Relations of social goal pursuit to social acceptance, classroom behavior, and perceived social support. Journal of Educational Psychology, 86, 173-182.

[29] Wentzel, K. R. (1998). Social relationships and motivation in middle school: The role of parents, teachers, and peers. Journal of Educational Psychology, 90, 202-209.

[30] Woolfolk, A.E., Rosoff, B., \& Hoy, W.K. (1990). Teachers' sense of efficacy and their beliefs about managing students. Teaching and Teacher Education, 6, 137-148.

[31] Wolters, C. A., \& Daugherty, S. G. (2007). Goal structures and teachers' sense of efficacy: their relation and association to teaching experience and academic level. Journal of Educational Psychology, 99, 181-193.

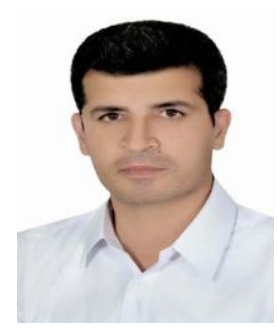

Ahmad Mojavezi was born in 1974 in Iran. He holds an MA degree in language teaching from Najafabad University. He is also a PhD. Student in Applied linguistics in Iran. He is an academic staff member at Islamic Azad University, Zahedan branch in Iran. His principal research interest is in psychology, more specifically, learning strategies and working memory. He is teaching courses in Teaching Methodology and Learning Strategies. He has also presented papers in national and international conferences

Marzieh Poodineh Tamiz was born in 1975 in Iran. She is a teacher in Special Education Ministry. Her principal research interest is in teacher education. 